\title{
CONTEXTUAL APPROACHES IN KAIWA LEARNING (SPEAKING) JAPANESE LANGUAGE
}

\author{
J R R Wuisang ${ }^{1}$ \\ ${ }^{1}$ Universitas Negeri Manado, Indonesia \\ corresponding author: ${ }^{1}$ justienwuisang@unima.ac.id
}

\begin{abstract}
Speaking as one of the productive language skills and is an important activity in daily activities as meaningful interaction between humans is still not optimal in the Japanese language study program from an explanation before, this purpose of this study is to achieve the goal of speaking skills; the permitted curriculum in the Japanese Language Education study program, the development competency based curriculum in 2009 provides courses: Kaiwa 1 (会話 1) Conversation 1、Kaiwa 2 (会話 2) Conversation 2、Kaiwa 3 (会話 3) Conversation 3、 Kaiwa 4 (会話 4) Conversation 4、Kaiwa Enshuu (会話 演習) Conversation Deepening and one special course for Japanese speech skills, Nihongo Supiichi (日本語 ス ピー チ) Japanese Language Speech. In line with that idea, an important strategy in this learning is to teach students to be able to connect each concept with reality rather than emphasizing how much knowledge must be remembered and memorized. This research used CTL approaches which is contextual learning can be applied in any curriculum, any subject or field of study with a class regardless of the circumstances. In line with what was discussed by the Ministry of National Education, there are Seven (7) main principles that must be developed by teachers in the CTL approach. The contextual approach in Kaiwa learning is also expected to facilitate the achievement of learning goals, namely the aim of speaking Japanese skills to improve students' speaking abilities and provide many opportunities for the practice of talking with friends while making students actively involved in the learning process. Therefore, it is recommended that in Kaiwa learning (the name of the course for speaking skills in Japanese), I - IV this contextual approach can be used even maximized. The researcher realizes that this learning model is not the only one that is most suitable and relevant in teaching Japanese speaking skills courses but can be used as enrichment material.
\end{abstract}

Keywords: Contextual Approaches; Kaiwa Learning; Speaking; Japanese Language. 


\section{Introduction}

In language activities, someone communicates more verbally compared to other ways. By talking someone tries to express all feelings and thoughts to others verbally. In other words speaking activities are expressions of all language skills a person has through a combination of various actions to achieve goals. The intended purpose is the creation of mutual understanding between speakers and listeners as the purpose of the communication itself. Speaking skills are one of the productive language skills and are important activities in everyday life. Therefore someone's speaking skills especially the prospective teachers are absolutely necessary.

Speaking as one of the productive language skills and is an important activity in daily activities as meaningful interaction between humans is still not optimal in the Japanese language study program, in terms of verbal communication using Japanese between students and students on campus still very lacking, when meeting lecturers or guests from the Japanese-speaking community, speaking in Japanese students is still very low. Even worse when meeting native Japanese speakers, many are silent and hardly want to talk. Daily communication both on campus during study hours and off campus between students tends to use everyday language or mother tongue.

To achieve the goal of speaking skills; the permitted curriculum in the Japanese Language Education study program, the development competency based curriculum in 2009 provides courses: Kaiwa 1 (会話 1) Conversation 1 、Kaiwa 2 (会話 2) Conversation 2、Kaiwa 3 (会話 3) Conversation 3、Kaiwa 4 (会話 4) Conversation 4 、Kaiwa Enshuu (会話 演習) Conversation Deepening and one special course for Japanese speech skills, Nihongo Supiichi (日本語 スピーチ) Japanese Language Speech. These courses are still integrated using the Minna no Nihongo textbook package (みんなの 日本語) which is currently very commonly used by institutions that carry out Japanese language teaching.

The Japanese Language Education Program has many textbooks used by lecturers. From textbooks collected by study programs and lecturers' personal collections, materials or teaching materials are prepared by lecturers in these courses. The textbook that is currently being used as a reference by the study program is the Minna no Nihongo (みんのの 日本語) textbook from 3A Corporation Tokyo Japan, which has just entered its fourth year of replacing the previous textbook Nihongo Shoho (日本語 初 歩). Included are books for speaking skills of Renshuu C. Kaiwa Irasutoshito (練習 C. 会話イラストシート). Minna no Nihongo book consists of Minna no Nihongo I and Minna no Nihongo II complete with main book (main book) for grammar teaching, translation books and explanations in Indonesian, books for writing Japanese letters and work books; books for listening skills, reading skills and speaking skills; which is also equipped with an audio $\mathrm{CD}$ and other supporting books, namely instructions for use for lecturers (instructors). The learning units consist of 25 topics on Minna no Nihongo I and 25 topics on Minna no Nihongo II. For speaking skills in the main book specifically on renshuu C (練習 C) in the form of examples of short conversations; and workbooks in the form of pictures of examples of conversational situations based on topics in the main book. In addition, on its own initiative, lecturers in speaking skills use other textbooks available in the study program library. 
Anticipating any possible changes as the dynamics of the world continue to change and become more competitive, every public institution is challenged to continue to produce products that are ready to use. Each institution is required to be responsive to all forms of change as well as market and stakeholder needs. In the context of improving quality, it must also be continuous and must be more advanced than its competitors. The same thing applies to the FBS Unima Japanese Language Education Study Program where in speaking skills learning, to increase the proper use of teaching materials for $\mathrm{C}$ Cen the Minna no Nihongo teaching book, it is necessary to develop with reference to the context in addition to the hajimari part (opening ) and naiyou (contents) and owari (cover). Since implementing the 2009 curriculum that recommended the use of Minna no Nihongo's teaching book, it will carry out evaluations in the near future regarding the achievements and constraints faced, and whether to use the textbook as a source and reference for various language skills.

\section{Theoretical Base}

\section{Skills in speaking Japanese}

The various limitations put forward by experts such as Valelte who say that speaking is a social skill. Because in this speaking process there is a transformation of someone's information, ideas, ideas to others in which there is interaction between speakers and speech partners. Scott expressed his view that speaking is an oral communication activity involving two or more people where the participants play a role, both as speakers and who react to what they hear. While in the opinion of Penny Ur, a person's knowledge of a language can be indicated by his skill in speaking in a language. Someone said to master a particular language is not a result of mastery of grammar and vocabulary, but more than the ability to use the language in accordance with its purpose as a means of communication. In language, competency is a basic knowledge of the system of grammatical languages, the vocabulary of all language trinkets and how to use them in a unified manner. Speaking and writing according to Brown is performance or actual production while listening and reading is an understanding of linguistic events. As one of four language skills.

Speaking is a complex skill and is related to micro and macro skills. As micro skills (microskills), speaking is (a) a skill that produces varied utterances; namely the diversity in the length of the cut language used, (b) the ability to produce phonemes and segmental phoneme variants, where this skill requires knowledge of the system and sound patterns in a particular language, (c) skills in producing pressure patterns, rhythmic structure and intonation as suprasegmental phonemes, which help to talk about avoiding misunderstandings in conveying messages, (d) skills in producing shortened words and phrases, (e) skills using appropriate words, (f) skills producing conversations that are fluent in various different speeds, (g) skills of observing the spoken language produced and using various varied strategies, (h) skills in mastering language forms; including categories of words, sentence patterns, tenses and so on, (i) skills in producing speech that use natural elements, (j) skills to express certain meanings in different grammatical forms. As macro skills (makroskills) speaking is (a) the skill of using cohesive forms in oral discourse, (b) the skill of completing communication functions with appropriate situation, participation and purpose of communication, (c) skills using pragmatic rules and appropriate sociolinguistic 
features, (d) Skills in communicating the relationships between main ideas and supporting ideas, old information and new information, generalizations and examples, (e) skills using facial language, kinesthetic, body language and other nonverbal languages together with verbal language, (f) the skill of developing and using various speaking strategies such as emphasizing key words, paraphrase, providing context for interpreting word meanings, asking for help and appropriately assessing how well the interculator understands what is being said.

Still within the framework of language skills, especially speaking skills, Canale and Swaim suggest that speaking skills also require mastery of four other language competencies, namely: grammatical competence (discourse competence), sociolinguistic competence (sociolinguistic competence), and strategic competence (strategic competence) grammar competencies are grammar knowledge competencies which are related to dictionaries (vocabulary mastery), morphological, syntactic, semantic and phonological rules. Discourse competency is the ability to combine ideas or thoughts that will be delivered in the right order according to the communication objectives to be achieved. Sociolinguistic competence is the ability to use grammar in the right context, can be understood by native speakers, and does not deviate from the socio-cultural rules of the community. Strategic competencies are verbal and non verbal communication strategies that can be used to compensate for congestion in communication due to performance variables or due to inadequate competence.

As communicative competence was initiated by Canale and Swain, Littlewood argued that there are four major domains of speaking skills that a person must possess, namely: (1) skills using the linguistic system to the level of being able to use it spontaneously and flexibly, (2) the skills to distinguish forms which is mastered as part of linguistic competence with communicative functions. In other words, it can place linguistic systems as part of the communication system, (3) skills in using language to communicate meaning in real situations as effectively as possible, (4) skills of awareness of the social meaning of each form of language so that they can use acceptable forms.

From the four domains above, it can be concluded that language learners need to be given the freedom to express and develop appropriate strategies according to language functions. As Brown argues that function is a goal that we achieve with language, for example stating, asking, responding, greeting, saying goodbye, and so on. However, functions cannot be fulfilled without language forms such as: morphemes, words, grammar rules, discourses and other organizational competencies. So it is clear and it can be concluded that form is an outward manifestation of language, while function is an embodiment of those forms. No less important in speaking skills is the importance of accuracy and fluency in speaking. Accuracy is related to language forms while fluency is related to language functions.

Speaking in Japanese is called Hanasu 話 す which according to Houjou defines "話話Icara などがある。 talking is a communication between humans and humans to convey their intentions to each other which can be one person to another, one person to many people or vice versa. However, this limitation is of course different from Kaiwa's understanding 会話 in this study which according to 
Matsuura as "conversation" as in the phrase 会話 力 ... as the ability to speak verbally or 日本語 の会話 の練習 する ... practice conversing in Japanese.

The two Japanese words above, both Hanasu and Kaiwa are speaking activities which in principle according to Tarigan need to pay attention to several factors such as (1) pronunciation of language, (2) intonation and accents, (3) accuracy in pronunciation that reflects understanding of the language used, (4) the use of appropriate structures, (5) fairness and fluency in the use of language, (6) expressions according to the content of the conversation.

The speaking skills intended in this article are verbal (verbal) skills in a second language in Japanese. Speaking skills are among the mastery that must be possessed for the ability to perform in language skills besides; listening (listening = chookai), reading (reading $=$ dokkai) and writing (writing $=$ sakubun). As with other foreign languages, one of the competencies that must be achieved in conducting language learning in the Japanese Language Education Program FBS UNIMA is speaking competence. To achieve these competencies there are three courses related to efforts to improve speaking skills, namely: Kaiwa (会話) I-IV, Kaiwa enshuu (会話 演習) and Nihongo supiichi (日本語 ス ピーチ).

\section{Contextual Approach in Language Teaching \\ a. General understanding}

The basic concept of contextual learning is an approach to learning with teaching activities from teachers that connect learning material with real-world situations and learning activities that motivate students to connect and apply their knowledge to everyday life as family members and society.

In the context of learning there are several terms that have similarities in meaning, namely; learning approaches, learning strategies, learning methods, learning techniques, learning models. The learning approach can be interpreted as our starting point or point of view of the learning process that refers to the view of the occurrence of a process. Judging from the approach, learning is divided into two types, namely: (1) a learning approach that is oriented or student-centered (student centered approach) and (2) a teacher-oriented approach.

Contextual Teaching Learning is a contextual translation (CTL). The term contextual means the relationship, context, atmosphere or situation so that CTL can be interpreted as a learning that relates to a particular atmosphere. The philosophical foundation of CTL is constructivism, which is a learning philosophy that emphasizes that learning is not just memorizing but must construct knowledge. Contextual Teaching Learning, is a holistic learning concept that emphasizes learning with the real world; which helps the teacher relate the material being studied in class to the real-world situation of students. Students are also helped to connect every knowledge they have by applying in the context of the lives of their peers, their families and the environment and surrounding communities. In line with the above formula, Mulyasa argues that in the learning strategy as the implementation of the Competency Based Curriculum (Contextual Teaching Learning), Contextual Teaching Learning is one of the five learning models that are considered in accordance with the requirements of the $\mathrm{CBC}$ in addition; Role Playing, Participatory Teaching and Learning, Mastery Learning and Modular Instruction. 
Contextual learning is the latest learning concept developed to extract learners who are able to think creatively and act decisively and intelligently. This learning process is motivated by the constructivism theory that requires students to be able to build knowledge little by little, the results of which are expanded through their own context without being given directly by the teacher / lecturer (knowledge transfer). According to Zahorik, there are five elements that must be considered in contextual learning, namely: (1) activation of existing knowledge (activating knowledge), (2) acquiring new knowledge (acquiring knowledge), (3) understanding of knowledge (4) ) practicing knowledge (5), reflecting (reflecting knowledge).

Judging from the approach, contextual learning is a learning approach that is oriented or student-centered (student centered approach) and has the following characteristics: (1) Students are actively involved in learning, (2) in learning, students collaborate to establish knowledge (3) learning is associated with real life so that problems can be simulated, (4) behavior built on self-awareness, (5) skills developed based on the results of understanding, (6) gifts for good behavior are satisfaction. Whereas according to Muslich, learning with a contextual approach has 7 characteristics, namely: (1) learning is carried out in an authentic context, namely learning directed at achieving skills in real life contexts or learning in a real life setting, (2) learning provides opportunities for students to do meaningful learning, (3) learning is carried out by providing meaningful experiences to students (learning by doing), (4) learning is carried out through group work, discussion, correcting each other between friends (learning in group), (5) learning provides an opportunity to create a sense of togetherness, mutual understanding between one another in depth (learning to know each other deeply), (6) learning is carried out actively, creatively, productively and memmentingkan cooperation (learning to ask, to inquiry, to work tog ether), (7) learning is carried out in a pleasant situation (learning as enjoy activity).

Contextual learning requires cooperation between all parties. This trains students to respect each other's differences in order to achieve learning goals. So that cooperative learning is one of the characteristics in learning foreign languages, including Japanese.

In contextual learning the task of the teacher is as formulated by Mulyasa, which is to provide learning convenience to students by providing various facilities and adequate learning resources, as well as regulating the environment and learning strategies conducive to learning activities by paying attention to five elements: (1) learning must pay attention to the knowledge possessed by students, (2) learning starts from the whole (global) towards its parts specifically (from general to special). (3) learning must be emphasized in understanding by: arranging temporary concepts, sharing with others, revising and developing concepts, (4) learning emphasized in the effort to practice directly, (5) reflection on learning strategies and developing the knowledge learned.

Contextual learning provides opportunities for learners to explore material with real life everyday. As Johnson said, the partnership allows students to apply academic lessons to the workplace, where lessons are linked to everyday tasks and experiences. allows learning by doing. Where the main message of learning by doing is making learning that connects with everyday life produces meaning so that it is absorbed and mastered by learners in the form of knowledge and skills. 


\section{b. Characteristics of Contextual Learning}

According to the Ministry of National Education, contextual learning (CTL) has the following characteristics: (1) cooperation, (2) mutual support, (3) fun, not boring, (4) passionate learning, (5) integrated learning, (6) using various sources, (7) active students), (8) sharing with friends, (9) critical students, creative teachers, (10) classroom walls and hallways filled with student work, maps, pictures, articles, humor, etc., (11) reports to parents are not only report cards, but students' work, reports on lab results, essays and so on.

Whereas according to Nurhadi, contextual learning has eight components as characteristics of CTL, namely:

1) Making meaningful connection (making meaningful connections), encourages students to find a connection between the material being studied and the real world situation.

2) Doing significant work (doing meaningful work) encourages students to do work that is meaningful, purposeful, useful and has tangible products or results

3) Self-regulated learning (conducting learning on its own), students can organize themselves in learning that is tailored to their abilities, talents and interests in developing their own potential.

4) Collaborating (collaborating), students collaborate in learning, both with other friends and with teachers, and other people.

5) Critical and creative thinking, students are encouraged to think higher levels such as; analyze, solve problems, make decisions, use logic, and form arguments based on facts.

6) Nurturing the individual (maintaining or caring for students), learning must be able to form the personality of students well as well as motivate to tolerate other friends.

7) Reaching high standards (achieving high standards), students are encouraged to diligently and diligently study to achieve better standards.

8) Using authentic assessment (using authentic assessment), assessment of students is not only done at the end of learning activities, but also takes place when the learning process takes place. And the assessment carried out should assess what should be assessed.

Contextual learning is a system consisting of related and related components. The components in question will function properly if the three principles of contextual learning are carried out. The three principles are: interdependency, difference, and self-regulated. First is the principle of interdependence, that an institution is a system of life consisting of (students / students, teachers / lecturers, principals / deans, administrative employees, parents / guardians, alumni, communities) who are in a network of relationships that shape the learning environment . Students / students as one part of it, will make it possible to establish meaningful relationships with other parts. Second, the principle of diversity, in the context of the learning environment, schools, faculties, universities as a learning environment that consists of diverse and different entities and is loaded with each other's uniqueness. The principle of differentiation encourages mutual cooperation, respect for diversity and uniqueness. Synergy between each entity will encourage endless creativity to create an orchestra that is harmony that is harmony of life. The 
three principles are self-regulation, where everything is governed by oneself, maintained by oneself, realized by oneself. When students connect the material to the context of their personal circumstances or the social environment in which they live, they are involved in self-regulation activities.

\section{b. Principles of Contextual Learning}

CTL or contextual learning can be applied in any curriculum, any subject or field of study with a class regardless of the circumstances. In line with what was discussed by the Ministry of National Education, there are Seven (7) main principles that must be developed by teachers in the CTL approach, namely:

\section{1) Constructivism (Constructivism)}

Constructivism is the foundation of thinking (philosophy) in CTL. Knowledge gained by humans little by little the results are expanded through a limited context. Knowledge is not a set of facts, concepts or rules that are ready to be taken and remembered. Rather, humans must build that knowledge, give meaning through real and not sublime or instant experiences. Students are accustomed to solving problems, finding something useful for themselves and must be rich in ideas and innovations. So constructivism is an activity that develops the idea that learning will be more meaningful if the learner is: the student or student works, finds and builds his own knowledge and even new skills. Assuming that the teacher is not able to construct all knowledge to students so that the essence of constructivism theory is that students must find and transform complex information into other situations even if it is possible that information becomes their own.

An important strategy in this learning is to teach students to be able to connect each concept with reality rather than emphasizing how much knowledge must be remembered and memorized. Research carried out reveals the fact that mastery of the theory has a positive impact in the short term but does not contribute well enough in the long run. In other words, rote theoretical knowledge is easily separated from memory if it is not supported by real experience. Thus the basic principles that must be considered when implementing constructivism are: (a) prioritizing the process rather than the learning outcomes, (b) prioritizing meaningful and relevant information rather than verbalistic information, (c) the widest opportunity for learners to find and apply his own ideas, (d) students have the freedom to apply their own strategies, (e) students' knowledge grows and develops through their own experience, (f) understanding will be stronger and continue to develop if always tested with new experiences.

For teachers; both teachers and lecturers have implications in developing this constructivism stage, especially the ability to guide students to get meaning from each concept that is learned. That is why every teacher must have sufficient knowledge to provide illustrations, use learning resources, and learning media that can stimulate students to actively seek out and do and find their own links between concepts learned and their experiences.

\section{2) Inquiry}

Finding, is a core activity in CTL, through efforts to find, will provide confirmation that the knowledge and skills and other abilities needed are not the result of remembering a set of facts, but are the results of finding themselves. Finding, is a learning activity that conditions the environment so that students either 
individually or in groups can make observations, investigations, analyze to find or make conclusions on the topic or subject matter that is being faced in accordance with their respective experiences. Besides that, it was seen in terms of emotional satisfaction, a finding result alone had higher satisfaction compared to the results of giving.

Teachers in inquiry learning activities must always design activities that refer to finding activities, whatever the material being taught. Because to grow the habits of students creatively in order to find their own learning experience has implications for the strategies developed by the teacher.

The inquiry cycles are (1) observation (observation), (2) questioning (asking), (3) hypothesis (submitting a guess), (4) data gathering (collecting data), and (conclusion) 5. The basic principles for implementing inquiry in learning are: (a) information will be longer when finding themselves, (b) information will be stronger if supported by evidence or data found alone, (c) cycles of inquiry usually through stages observation, asking questions, submitting allegations, collecting data and drawing conclusions.

\section{3) Questioning}

Asking activities is equally important as the main characteristic of CTL learning. The ability to ask questions and ask questions must be possessed by someone because someone's knowledge always starts with curiosity, and curiosity is done by asking questions. Asking questions is an activity that develops the idea that learning will be more meaningful if students work, discover and build their own new knowledge and skills.

Asking is the main learning strategy based on CTL. Asking in learning is an activity for teachers to encourage, guide and assess students' thinking skills because, as in the previous stages, the development of abilities and desires to ask questions is very important. . In the implementation of CTL, the questions must be used as tools or approaches to explore information or learning resources that have to do with real life. In other words, the teacher was asked to find out about the relationship between students and students in relation to real life.

(A) extracting information both academically and administratively will be more effective, (b) the confirmation of what students know is more effective, (c) increasing student responses, (d) knowing more student curiosity, (e) focus student attention, (f) refresh the knowledge they have.

In all learning activities, questioning can be applied both between students and students, teachers with students, between students and teachers, or between students and others brought in class, and so on. This activity is also carried out when discussing, studying and working in groups, while observing and other activities.

\section{4) Learning Community}

Learning society, is an activity that familiarizes students to collaborate and utilize learning resources from their learning friends. Learning society is a learning activity that creates an atmosphere of 'learning together' in mutual discussion, helping one another with each other. Thus creating positive interdependence developed. Learning community activities suggest that the results of learning are obtained from working with others through various experiences. In other words strong encourages his friend to be weak, who quickly catches on helping the sluggish, who is good at teaching those who don't know, who has an idea to 
immediately propose and so on so that groups of students will vary greatly in form; both membership numbers, can even involve other friends in the upper class, even bring in other people who are experts to collaborate.

The application of learning community in classroom learning will depend largely on the learning communication model developed by the teacher. Ability and ability and professionalism of a teacher to develop multiple-way communication (interaction), namely a communication model that is not only the relationship between the teacher and students or vice versa but broadly opened the path of communication between students and other students.

The basic principles that must be developed in the application of a learning society are: (a) learning outcomes obtained from cooperation or sharing with other parties, (b) sharing in question is two or even multi-directional, (c) awareness of each party that the knowledge, experience, and skills possessed will benefit others, (d) those who are considered as learning resources are those who are involved in the learning community.

The practice of implementing and developing learning communities within CTL is very possible and opened with extensive use of other learning communities outside the classroom. And the practice in learning is manifested in (a) the formation of small groups, (b) the formation of large groups), (c) bringing experts into the class (native speakers, doctors, clergy, sportsmen and so on), (d) working with classes parallel or equivalent, (e) workgroups with kelsa on it or with the community.

\section{5) Modelling}

Modeling or modeling is one solution to the limitations of teachers who have been regarded as the only source of learning. The development of science and technology, the complexity of life problems faced and the demands of students who are increasingly developing and diverse greatly affect the ability of teachers who have perfect abilities and this is very impossible and difficult to fulfill. Therefore the modeling stage can be used as an alternative to developing learning.

Modeling is a learning activity that brings models, for example, which are commonly used as reference material, references through the appearance of figures, demonstrations of activities, the appearance of works, how to operate things, play roles and so on. In learning something there is a model that can be replicated. Examples of speaking: how to imitate saying or reciting words or sentences in Japanese. Thus the teacher simply teaches how to learn by presenting the model by presenting the original Japanese castors into the learning class.

The basic principles that need attention in applying modeling in learning are: (a) the acquired knowledge and skills are more stable with the model that can be replicated, (b) the model or example can be directly from the original or expert, (c) model or example in the form how to say something, operate something, sample work, or model appearance.

\section{6) Reflection}

Reflection is a way of thinking about what just happened or just learned. In other words, reflection is thinking back to reflect back on things or anything that has and has happened in the past. Reflection or feedback, is a learning activity by making a reflection of the activities that have been carried out, such as through questions and answers about the difficulties faced and how to solve them, reconstruct the steps of activities that have been carried out, impressions and messages of hope during 
activities, draw conclusions about activities, and so on. Students settle with what they have just learned as a new knowledge structure which is enrichment or revision of previous knowledge. The key is how that knowledge settles in the minds of students. Students record what they have learned and how to apply new ideas.

During reflection, students get the opportunity to digest, weigh, compare, appreciate, and conduct discussions with themselves (learning to be). Through the CTL model, learning experiences not only occur and are owned when a student is in the classroom but far more important than that is how to bring the learning experience out of class, namely when he is required to respond to and solve real problems he faces a day -day. This is related to the ability to apply knowledge, attitudes, and skills to the real world, the world of work will be easily actualized when learning experiences have been internalized in the souls of students, is the core of the application of elements of reflection in every learning opportunity.

Realization of the moment given by the teacher in the application of reflection is in the form of (a) a direct statement of what he obtained at that time, (b) notes in the student book, (c) impressions and suggestions of students about learning, (d) discussion, (e) masterpiece. While the basic principles that must be considered are: (a) contemplation of new knowledge obtained as an enrichment of previous knowledge. (b) contemplation is a response to the events, activities, or knowledge acquired, (c) contemplation can be in the form of brief notes, discussions or work.

\section{7) Authentic Assessment}

Assessment is the final stage of contextual learning, the assessment of learning has a very decisive function to obtain information on the quality of the processes and learning outcomes in implementing CTL. Authentic assessment is a process of collecting various complete data and information that can provide an overview of student learning progress. An overview of the development of student learning is important to be known by the teacher in order to ensure that students experience the learning process correctly so that students' shortcomings can be known earlier by identifying data.

The basic principles that must be considered when applying authentic assessment in learning are: (a) assessment is not to judge students, (b) assessment must be comprehensive and balanced between process and results, (c) authentic assessment allows students to conduct self-assessments ) and peer assessment, (d) assessment is carried out by various evaluation tools on an ongoing basis as an integral part of the learning process, (e) assessments can be used by various parties both students, parents/guardians, and schools to diagnose learning difficulties , feedback and determine student achievement.

Authentic assessment characteristics: (a) carried out during and after the learning process takes place, (b) used in formative and summative, (c) continuous, (d) integrated, (e) can be used as feedback. And things that can be used as objects of assessment: (a) project activities and reports, (b) homework, (c) quizzes, (d) work results, (e) student presentations or performances, (f) demonstrations, (g ) report, (h) written test results, (i) written work.

In general, there is no fundamental difference between conventional learning program scenarios and CTL learning. But what distinguishes it lies in the emphasis, where the conventional model emphasizes the description of the objectives (results) that will be achieved (clear and operational), while CTL learning emphasizes more 
on the scenario (process) of learning, namely the stages carried out by teachers and students in efforts to achieve the expected learning goals. Therefore a teacher/lecturer contextual learning program should: (1) state the main learning activities, namely a student statement which is a combination of competencies, main material, and indicators of learning achievement, (2) clearly formulating the general goals of learning, (3) describe in detail the media and learning resources that will be used to support the expected learning activities, (4) formulate step-by-step scenarios of activities that students must do in the learning process, (5) formulate and conduct assessment systems by focusing on the ability actually what students have both during the learning process and after they finish learning. ${ }^{1}$

\section{Results and Discussion}

How to apply the seven main components of contextual learning in learning Japanese specifically speaking skills (kaiwa) are as follows:

\section{1) Constructivism}

Constructivism in speaking learning (kaiwa 会話) can take place if the students themselves learn to pronounce or pronounce words, phrases, expressions or sentences properly and correctly and the appropriate intonation. In learning to speak usually begins with imitation (modeling) several times repeated both through cassette recordings, CDs and speech immediately followed by demonstrations. Usually, the demonstration is carried out first by students who are considered capable and fast, then followed by others. And all students are tried to be involved in speaking activities. Students are also divided into groups and asked to demonstrate or demonstrate the practice of speaking in Japanese. Such activities provide opportunities for students to build their own knowledge based on their respective abilities.

\section{2) Questioning}

In learning to speak, there is a great opportunity for students to ask questions when students have difficulty expressing intent in the target language. Differentiate questioning at the end of learning activities when learning takes place.

\section{3) Finding (Inquiry)}

In speaking learning, inquiry can be done by giving assignments to students in groups to have conversations related to the theme/topic of learning. And this method is very appropriate because all students are actively involved and try to find as much information as possible both new words, conversation situations and so on.

\section{4) Learning Community (Learning Community)}

Learning communities in speaking learning (kaiwa 会話), can be done when students in their respective groups or with other groups share information by doing the target language in Japanese. Students who are considered capable will become tutors for other friends.

\section{5) Modeling}

In all language learning, modeling or modeling is very often done. Through modeling, it will be followed by stages of imitation (imitation). Especially in speaking skills learning, usually given examples of reciting words, phrases,

\footnotetext{
${ }^{1}$ Rusman. Model-model pembelajaran, Mengembangkan profesionalisme guru (Jakarta: Rajawali Pers) PT Raja Grafindo Persada. 2011.h.199.
} 
expressions, sentences that build a conversation situation, played a cassette or shown a $\mathrm{CD}$ and then the imitation stage goes on.

\section{6) Reflection (Reflection)}

In learning speaking skills; reflection can be done when students see or hear the model then give or take special and important notes on new things and are considered important. It is necessary to distinguish between reflection in this process with reflection at the end of the learning activity.

\section{7) Authentic Assessment}

The main purpose of authentic assessment is to know the progress or development of student learning. The assessment sheet is needed to observe how each student is capable, the performance sheet to determine the level of seriousness. So for students who experience difficulties can be done repetition and students who are considered capable may act as tutors for other friends to provide guidance and assistance.

\section{Closing}

The contextual approach in Kaiwa learning as Japanese speaking skills includes the use of various learning media such as video, audio, LCD, vocabulary lists, conversation materials taken from other Japanese language book sources or made by lecturers according to the topic or subject matter, and media created by students. This teaching material model component also includes assessment techniques or tests that are not only oral forms but also written tests. This teaching material should also contain text and individual exercises or even groups or pairs and be equipped with guidance for lecturers, while for students given teaching material as a guide when learning as well as strengthening skills according to the learning objectives. The contextual approach in Kaiwa learning is also expected to facilitate the achievement of learning goals, namely the aim of speaking Japanese skills to improve students' speaking abilities and provide many opportunities for the practice of talking with friends while making students actively involved in the learning process.

Therefore, it is recommended that in Kaiwa learning (the name of the course for speaking skills in Japanese), I - IV this contextual approach can be used even maximized. The researcher realizes that this learning model is not the only one that is most suitable and relevant in teaching Japanese speaking skills courses but can be used as enrichment material.

\section{References}

Bloomfield, Leonard. Language.New York : Holt,Reinhart \& Winston. 1993

Brown H.Douglas. Principle of Language Learning and Teaching $\left(5^{\text {th }}\right.$. ed), New York .Pearson Education, Inc.2001

Brown, D. James. The Elements of language Curriculum: A systematic Approach to Programme Development, 1995

Gall, Meredith D., Joyce P. Gall dan Walter R.Borg. Educational Research An Introduction, USA: Pearson Education. 2007

Houjou Junko. 1984. Nihongo Kyouiku Jiten. Tokyo : Bonjinsha Kida, Mari, dkk. Hanasu Koto wo Oshieru. Tokyo: The Japan Foundation, 2009 
Journal of Educational Method and Technology Vol. 2 No. 1, April 2019

P-ISSN 2622-8459 E-ISSN 2622-8467

http://ejournal.unima.ac.id/index.php/jemtec

Masuura Kenji, Kamus Bahasa Jepang-Indonesia. Kyoto : Kyoto Sangyo University Press. 1994

Mulyasa, E. Menjadi Guru Profesional : Menciptakan Pembelajaran yang Kreatif dan Menyenangkan. Bandung : Rosdakarya, 2007

Muslich, Masnur. KTSP : Pembelajaran Berbasis Kompetensi dan Kontekstual. Jakarta : Bumi Aksara, 2007

Nunan, David. Designing Tasks for Communicative Classroom. USA : Cambridge University Press, 1993

Richard C.Jack, Curriculum Development in Language Teaching, Cambridge: Cambridge University Press, 2005.

Richard C.Jack dan Renandya A.Willy . Methodology In Language Teaching , Cambridge: Cambridge University Press, 2003.

Rusman. Model-Model Pembelajaran,Mengembangkan Profesionalisme Guru, Jakarta : Raja Grafindo Persada, 2011.

Sakura Ridwan.2011, Metodologi Pemelajaran Bahasa, Aplikasi Dalam Pengajaran Morfologi dan Sintaksis; Yogyakarta : Kepel Press.

Tarigan, H.G. Berbicara Sebagai Suatu Keterampilan Berbahasa. Bandung : Angkasa, 2008

Tilaar, HAR. Perubahan Sosial dan Pendidikan. Pengantar Pedagogik Transformatif untuk Indonesia. Jakarta : Grasindo, 2002.

Tomlinson, Brian (Ed). Materials Development in Language Teaching.

London: Cromwell Press, Trowbridge, Wiltshire, 2007. 